\title{
Zapisivači i lokaliteti usmenoknjiževne zbirke Đure Deželića
}

Tanja Baran*

tbaran@hrstud.hr

https://orcid.org/0000-0002-2811-0346 https://doi.org/10.31192/np.19.1.7

UDK: 82-051Deželić, Đ. 821.163.42:398.5“18“

Pregledni članak / Review Primljeno: 7. kolovoza 2020. Prihvaćeno: 22. listopada 2020.

U radu se propitkuje mjesto nastanka opsežne rukopisne zbirke usmene književnosti nastale u 19. stoljeću, a pohranjene u Matici hrvatskoj pod imenom uglednoga hrvatskoga kulturnog djelatnika Đure Deželića. Budući da u rukopisu nisu navedeni točno mjesto zapisa niti imena kazivača, o lokalitetu se, kao i o samim zapisivačima, nastoji doznati kroz analizu tadašnjega hrvatskoga teritorijalnog ustroja te kroz jezik, odnosno narječje samoga zapisa usmenih lirskih pjesama. Iz istraživanja se zaključuje da sam Deželić najvjerojatnije nije sudjelovao u stvaranju te rukopisne zbirke kao zapisivač.

Ključne riječi: Đuro Deželić, lokalitet, rukopisna zbirka, usmena književnost, zapisivači.

\section{Uvod}

Razdoblje od posljednjeg desetljeća 18. stoljeća do četrdesetih godina 19. stoljeća u povijesti književnosti naziva se razdobljem romantizma. Nastalo je kao odgovor na dotadašnju klasicističku, veoma racionalnu književnost kojoj se u romantizmu suprotstavlja osjećajnost, buntovništvo i sloboda. Zato se u književnom stvaralaštvu tematiziraju osjećaji, mašta, putovanja, udaljeni krajevi, nacionalna prošlost i sukob s okolinom. Autori se nadahnjuju na povijesnim činjenicama, srednjovjekovlju i usmenoj književnosti.

Razdoblje romantizma u Hrvatskoj nije istovjetno romantizmu u zapadnoeuropskim zemljama. Specifičnost hrvatskih prilika uzrokovala je da se

\footnotetext{
* Doc. dr. sc. Tanja Baran, Sveučilište u Zagrebu, Fakultet hrvatskih studija, Borongajska cesta 83d, HR-10000 Zagreb; Hrvatska radiotelevizija, Prisavlje 3, HR-10000 Zagreb.
} 
književni romantizam pojavljuje kasnije i obuhvaća središnja desetljeća 19. stoljeća, a neka njegova obilježja vidljiva su poslije i kod Augusta Šenoe i u modernističkim strujanjima. Zahvaljujući raznim periodizacijskim kriterijima to je razdoblje kod nas različito nazivano. Zbog izrazitoga nacionalnog naboja s određivanjem općekulturnih smjernica, pa onda i stvaranja ključnih oblika književnoga stvaralaštva, prva je polovica 19. stoljeća u Hrvatskoj najpoznatija pod nazivom Hrvatski narodni preporod te unutar njega Ilirski pokret. U tom se vremenu politička i kulturna hrvatska stvarnost ravnopravno isprepleću i nadopunjuju. Nastaje političko buđenje i kulturno uzdizanje, narodno osvješćivanje, a onda i pojačano zanimanje za jezik i narodne običaje te za cjelokupno narodno stvaralaštvo. ${ }^{1}$

U teškim je društveno-političkim okolnostima onoga vremena hrvatsko književno stvaralaštvo, pisano na tri književna jezika, bilo u stagnaciji, a čakavski su i štokavski književni izričaji bili čak u padu. Svejedno se u tako složenim i nesređenim kulturnim i jezičnim okolnostima među mladom hrvatskom intelektualnom elitom budila nacionalna svijest s idejom kodifikacije jednoga hrvatskoga književnoga jezika kao osnovice hrvatskoga nacionalnog identiteta. U tim se nastojanjima izdvaja proglas biskupa Maksimilijana Vrhovca svećenstvu 1813. godine s pozivom na prikupljanje narodnog blaga i običaja. Makar su preporodne koncepcije u svojim djelima još puno ranije razvijali poznati hrvatski jezikoslovac Bartol Kašić, pisac prve hrvatske gramatike, i Andrija Kačić Miošić, pravim se pretečom preporoda s tezom o Slavenima kao jednom narodu i idejom o jedinstvenom jeziku i pravopisu smatra Pavao Ritter Vitezović.

U takvom ozračju is obavljenim pripremama kao vođa pokreta nametnuo se Ljudevit Gaj s više istaknutih istomišljenika. Prvi važniji dokument preporodne djelatnosti njegova je »Kratka osnova horvatsko-slavenskog pravopisanja objavljena 1830. godine s konceptom jedinstvenoga hrvatskog pravopisa. Ilirski je preporod započeo! Uslijedili su doprinosi Ivana Derkosa, Janka Draškovića, Antuna Mažuranića, Vjekoslava Babukića. Ilirski preporod obilježen je idejom o ilirskom imenu za sve slavenske narode, koje je poslije zabranjeno pa ponovno dopušteno samo u književnosti, osnivanjem ilirskih čitaonica, objavljivanjem časopisa »Danica« od 1835., novim poetskim žanrom - budnicama i davorijama, ali i raznim mimoilaženjima u razvoju Ilirskoga pokreta. Godine 1842. pojavio se novi književni časopis »Kolo« koji su predvodili Dragutin Rakovac, Ljudevit Farkaš Vukotinović i Stanko Vraz. Željeli su da u »Kolu« književne teme budu iznad društveno-političkih. Aktivno su im se pridružili Bogoslav Šulek i Dimitrija Demeter. Godine 1843. Ivan Kukuljević Sakcinski u Hrvatskom je saboru zatražio da hrvatski jezik bude službeni jezik Hrvatskoga sabora. Uskoro je, 1846., Ivan Mažuranić napisao najpoznatije djelo toga književnog razdoblja, spjev »Smrt Smail-age Čengića«.

\footnotetext{
${ }^{1}$ Usp. Dubravko JELČIĆ, Hrvatski književni romantizam, Zagreb, Školska knjiga, 2002, 14.
} 
U vrijeme je Ilirskoga preporoda Antun Mihanović 1835. napisao i objavio pjesmu »Horvatska domovina« koja je poslije uglazbljena i proglašena hrvatskom himnom. Ilirska je ideja na kraju propala, no u vremenu ilirizma riješena je problematika oko hrvatskoga pravopisa te je odlučeno da štokavska osnovica bude temelj za standardni književni jezik. U tom su se razdoblju svojim stvaralaštvom istaknuli: Petar Preradović, Mirko Bogović, Ivan Trnski, Dragojla Jarnević, Grgo Martić, Frano Jukić, Luka Botić, Miroslav Kraljević, Mato Vodopić, Adolfo Veber Tkalčević, Janko Jurković, Matija Mažuranić, Antun Nemčić. ${ }^{2}$ Većina je tih autora, osim što su imali svoju osobnu književnu preokupaciju, bilježila usmenoknjiževnu građu te se nadahnjivala brojnim i raznolikim usmenoknjiževnim poticajima.

\section{Usmena književnost u 19. stoljeću}

Usmena književnost na hrvatskom tlu postoji i bilježi se od najstarijih vremena. Do kraja 18. stoljeća prikupljeno je više od tisuću zapisa. ${ }^{3}$ Ekspanzija se dogodila u 19. stoljeću. Zato se to razdoblje drži najplodonosnijim vremenom zapisivanja usmene književnosti među Hrvatima. Zapisivalo se po poticajima uglednih hrvatskih kulturnih radnika i povjesničara, ali i ključnih kulturnih i znanstvenih ustanova onoga vremena. Prvi veći poticaj zapisivanju usmenoknjiževnoga blaga u vremenu uoči Hrvatskoga narodnoga preporoda dao je zagrebački biskup Maksimilijan Vrhovac. On je 26. lipnja 1813. godine uputio poziv svećenicima svoje biskupije na skupljanje narodnih umotvorina, poslovica, fraza, riječi i starih knjiga. Poziv je poslije objavio i u 24. broju Gajeve »Danice« iz 1837., i to u latinskom izvorniku i s »ilirskim « prijevodom. ${ }^{4}$ Svoju brigu o hrvatskom narodnom blagu Vrhovac je u pozivu posvjedočio sljedećim riječima:

»Prosti puk je vjeran čuvar mnogih popjevaka, koje služe obrazovanju jezika. Ugled pjesnika u svima je jezicima važan a tako i kod nas. Pjesme podržavaju opomenu na mir i rat, na velike muževe i vojvode, na običaj i navade, na religiju i ćud naroda, a uz to nam pokazuju i osebinu rieči, dužinu i kratkoću slovaka i genij čitavoga jezika. (...) Pozivljem vas, nukam i molim da osobite hrvatske i slavonske rieči, svakake poslovice i narodne pjesme, koje ste već sabrali i koje ćete u buduće sabirati, meni što brže saobćite (...) sakupljajte i malo po malo

\footnotetext{
${ }^{2}$ Usp. Miroslav ŠICEL, Hrvatska književnost 19. i 20. stoljeća, drugo nadopunjeno i prošireno izdanje, Zagreb, Školska knjiga, 1997, 49-72.

${ }^{3}$ Stipe BOTICA, Kontinuitet hrvatske usmene književnosti, u: Dunja FALIŠEVAC, Krešimir NEMEC (ur.), Umijeće interpretacije. Zbornik radova u čast 80. godišnjice rođenja akademika Ive Frangeša, Zagreb, Matica hrvatska, 2000, 143.

${ }^{4}$ Usp. Dubravko JELČIĆ, Hrvatski književni romantizam, Zagreb, Školska knjiga, 2002, 97.
} 
meni šaljite bilo koje mu drago pjesme i hrvatske i slavonske s primjedbama u koliko se može znati, kada po komu i kojom zgodom su izpjevane? « ${ }^{5}$

Zapisivači su bili nadaleko poznati prosvjetitelji, po svojem djelovanju važni za cjelokupan hrvatski prostor, ali i javnosti manje znani, a učeni, pismeni ljudi, ponajviše učitelji. Usmenu su književnost zapisivali najčešće prema pravilima koja su objavili ugledni pojedinci, poput biskupa Vrhovca, početkom 19. stoljeća, i Ivana Kukuljevića Sakcinskog, sredinom 19. stoljeća, ili prema pravilima institucija, poput Matice hrvatske ili Odbora za narodni život i običaje tadašnje JAZU iz sredine i kraja 19. stoljeća. S tim da su se tih pravila zapisivači rjeđe držali u potpunosti, a češće fragmentarno. Neki su zapisivali tek kao entuzijasti, ne držeći se nikakvih naputaka.

Među zapisivačima se našao i istaknuti hrvatski književnik i publicist, politički, kulturni javni djelatnik Đuro Deželić. Pod njegovim je imenom u Matici hrvatskoj u drugoj polovici 19. stoljeća pohranjen rukopis potpisan kao Đuro Deželić i drugi (I. Mirković St. I-nin, Matija Pajić, Ivan Stipac, Terezija Burazović i Primorac). Opsežan rukopis štokavskih i kajkavskih pjesama ${ }^{6}$ nije ispisan precizno u smislu točnog lokaliteta nastanka, niti su zabilježena imena kazivača. A čini se da sam Deželić osobno niti nije participirao u oblikovanju toga zapisa.

\section{Nastanak i porijeklo rukopisa, zapisivači i kazivači}

Đuri Deželiću ${ }^{7}$ pripisuje se velika rukopisna zbirka pjesama od pet cjelina ispisana na čak 695 stranica koju je tijekom gotovo trideset godina ostvarilo više zapisivača. Uz pojedine dijelove rukopisa potpisani su: I. Mirković St. I-nin,

${ }^{5}$ Usp. Velimir DEŽELIĆ, Maksimilijan Vrhovac (1752.-1827.), Zagreb, Tisak C. Albrechta, 1904, 193-195.

${ }^{6}$ Hrvatske narodne pjesme, »Štokavske i kajkavske pjesme« (151 lirska pjesma iz okolice Križevaca, Posavine [od Kratečkog do Siska], 7-135 i 36 pjesma iz Prigorja, 151-178), 1859, (1877), Arhiv Odsjeka za etnologiju HAZU, MH 186, prijepis IEF, rkp. 245.

7 Đuro Stjepan DEŽELIĆ, književnik i zagrebački gradski vijećnik (Ivanić Grad, 1838. - Zagreb, 1907.) Prozaik i publicist. Osnovnu školu polazio je u Ivanić Gradu, a klasičnu gimnaziju završio je u Zagrebu. Studirao je bogosloviju i pravo. Bio je službenik grada Zagreba, gradski vijećnik i zamjenik gradonačelnika Zagreba. Uređivao je list »Smilje« (1858), »Narodne novine« i »Danicu« (1864-1868) te književni časopis »Dragoljub« (1867-1868), a bio je i urednik prvoga godišta »Vijenca« (1869.). Prevodio je s njemačkog, ruskog i francuskog jezika. Priredio je i prvu antologiju hrvatske, srpske i slovenske lirike (Pjesmarica, 1865) te napisao više književnih djela (usp. Miroslav ŠICEL, Povijest hrvatske književnosti. Realizam, Zagreb, Naklada Ljevak, 2005, 243-244). Isticao se kao dobar i marljiv organizator $u$ više područja kulturnoga i javnoga života. Njegovim su nastojanjem podignuti mnogi dijelovi Zagreba, uređeni trgovi i izgrađen vodovod. Osnovao je vatrogasnu službu u Hrvatskoj (1868). Djelovao je kao član, odbornik i predsjednik više kulturnih i dobrotvornih društava. Pisao je povijesne i filozofske rasprave, političke članke, poeziju, pripovijesti, romane, putopise te životopise znamenitih sunarodnjaka. Služio se pseudonimima Stjepan Mirković, Milutin, Juraj Ivančanin, Stjepan Horvat, Lonjac, Ferdo Posavski, Samohrvat i dr. [usp. Karmen MILAĆIĆ, Đuro (Gjuro) Deželić, u: Hrvatski biografski leksikon, sv. 3, Zagreb, Leksikografski zavod »Miroslav Krleža«, 1993, 358-360]. 
koji je napisao i predgovor zbirci, Matija Pajić, Ivan Stipac, Terezija Burazović i Primorac. Identitet tih zapisivača nije poznat.

Građa je zapisivana u nekoliko navrata, od 1859. do 1886. Godine 1877. rukopis je Matici hrvatskoj, nakon njezina poziva za prikupljanje narodnih pjesama, predao Đuro Deželić uz opis da su sadržaj zbirke

»372 junačke i ženske pjesme, sabrane od 1857. do 1859. u križevačkoj Krajini i hrvatskoj Posavini od Kratečkoga prema Sisku i u Dolnjem Zagorju u Hrvatskoj i u Medjimurju u Ugarskoj. - God. 1877 «. $^{8}$

$\mathrm{U}$ tom najstarijem dijelu rukopisa, ispisanom na 243 stranice, usmenoknjiževni je korpus iz križevačkoga kraja. Može se pretpostaviti da je Deželić ili netko drugi u Matici hrvatskoj godinama nadopunjavao postojeći rukopis kada je od pojedinoga zapisivača dobio nove zapise.

Sljedeći su zapisi u rukopis uneseni 1879., 1880. i 1886. Druga cjelina, bez navedenoga datuma zapisa, odnosi se na »Bosanske pjesme« koje je u okolici Banje Luke, Sarajeva, Travnika i Jajca prikupio/la Matija Pajić. Riječ je o 80 lirskih pjesama koje su svoje mjesto našle od 244. do 331. stranice rukopisa.

Treća cjelina je »Zbornik Ivana Stipca iz Smiljana« iz 1879. U tom je rukopisu na stranicama 332. do 478., nakon uvodnog autorova pisma, ispisano 50 lirskih i kraćih pripovjednih pjesama.

Sadržaj su četvrte cjeline 144 kraće lirske pjesme koje je 1880. godine zapisala Terezija Burazović, učenica V. razreda djevojačke samostalne gimnazije u Požegi. Te su pjesme smještene od 479. do 655. stranice rukopisa koji se vodi kao »Zbornik Terezije Burazović. Pjesme iz Novske i Kraljeve Velike.«

Posljednji i najkraći dio rukopisa iz 1886. godine smješten je od 658. do 695. stranice Deželićeva zbornika. Pripisuje se Primorcu i donosi 29 lirskih pjesama iz Hrvatskoga primorja.

Cjelovito izdanje rukopisa čuva se u arhivu Odsjeka za etnologiju HAZU u zbirci Matice hrvatske. Ima signaturu MH 186, a dio rukopisa, u kojemu je građa iz križevačkoga kraja, u prijepisu čuva i Institut za etnologiju i folkloristiku, rkp. 245. Rukopis je tvrdo uvezan, ima višestruku paginaciju i višestruku numeraciju pjesama, formata je $18 \times 22 \mathrm{~cm}$.

Uz prvi i najstariji dio rukopisa u 55 . broju »Zbornika za narodni život i običaje« stoji sljedeći opis:

»Hrvatske narodne pjesme puka štokavskoga i kajkavskoga, sakupio I. St. Mirković I-Nin, a izdao Lavoslav Župan. U Zagrebu 1859.: a) Predgovor (str. 2-6); b) Štokavske pjesme (151 lirska pjesma iz okolice Križevaca, Posavine / od Kratečkog do Siska / str. 7-135); c) Kajkavske pjesme (202 lirske pjesme; str. 136-232 + 8 kraćih lirskih pjesama na manjem formatu; str. 233-243).«9

\footnotetext{
${ }^{8}$ Ivan Broz, Stjepan Bosanac (ur.), Junačke pjesme. Hrvatske narodne pjesme, knj. 1, Zagreb, Matica hrvatska, 1896, XIII.

${ }^{9}$ Zbornik za narodni život i običaje, br. 55, Zagreb, HAZU, 2010, 329-330.
} 
Kao lokalitet navodi se okolica Križevaca, okolica Siska (Posavina od Kratečkog do Siska), Hrvatsko zagorje i Međimurje.

U određivanju točnih lokaliteta zapisa Mirkovićeve zbirke nameće se nekoliko problema. U predgovoru rukopisa Mirković piše da su štokavske pjesme »iz Križevačke krajine i hrvatske Posavine od Kratečkoga ovamo pram Sisku«, a da je »kajkavština zastupana skoro iz svakoga kuta naše domovine jedino Gornje Zagorje izuzev« te da je »Dolnjo Zagorske« pjesme dobio. Kada se lista rukopis odmah se vidi da u štokavskom ciklusu od 151 pjesme nema nikakvoga određenja lokaliteta zapisa pjesama, a u predgovoru je kao lokalitet zapisa navedeno uistinu jako široko područje. Tek se iz dvije bilješke kao mjesto zapisa mogu iščitati i križevački kraj i Ivanić Grad. ${ }^{10}$ Po tome se može zaključiti da su te pjesme uistinu zapisivane na širokom hrvatskom prostoru, ali se nikako ne može rekonstruirati u kojem je kraju koja pjesma zapisana, osim u nekoliko pjesama, poput navedene dvije, u kojima je prema bilješkama vidljivo u kojem su kraju zapisane.

U usmenoknjiževnoj zbirci istaknutoga hrvatskog kulturnog radnika Ivana Kukuljevića Sakcinskog, koji je nešto ranije također zapisivao po Križevcima i okolici, navodi se da su pjesme iz Križevačke regimente, granice ili varmeđe, a u ovoj se tzv. Deželićevoj zbirci čak niti ne zna koje bi zapisane pjesme pripadale Križevačkoj krajini, a koje Sisku i Posavini. Kajkavski je dio zbirke, u kojem se numeracija vodi od početka, od broja 1 , klasificiran u 12 poglavlja. Riječ je o »Pjesmama magjarskih Hrvatah« (1. dio, pj. 1-17), o »Pjesmama iz Prigorja« (2. dio, pj. 18-54), »Pjesmama iz zagrebačke Posavine« (3. dio, pj. 55-56), »Pjesmama iz Varaždina« (4. dio, pj. 57-65), »Pjesmama iz Dolnjega Zagorja« (5. dio, pj. 66-97), »Pjesmama iz Turopolja« (6. dio, pj. 98-100), ponovno o »Pjesmama iz Dolnjeg Zagorja« (7. dio, pj. 101-127), »Pjesmama iz Posavine« (8. dio, pj. 128139), ponovno »Pjesmama iz Dolnjega Zagorja« (9. dio, pj. 140-185), »Pjesmama iz Megjimurja« (10. dio, pj 186-189), »Pjesmama iz Zagreba« (11. dio, pj. 190199) i »Pjesmama iz Moslavine« (12. dio, pj. 200-202).

Autorica ovoga rada pretpostavlja da je tih 36 pjesama iz Prigorja u drugom dijelu kajkavskoga dijela zbirke vezano uz križevački kraj, prije nego što bi to bile štokavske pjesme iz prvoga poglavlja Mirkovićeve zbirke koje su u predgovoru određene Križevačkom krajinom, Posavinom, Kratečkim i Siskom. Te »prigorske pjesme« i sadržajem i jezikom odgovaraju križevačkom usmenoknjiževnom korpusu, posebice kada se te pjesme usporede s ostalim križevačkim rukopisnima zbirkama pjesama koje su zabilježene u 19. stoljeću. ${ }^{11}$ Taj je

\footnotetext{
${ }^{10}$ U bilješci uz pjesmu br. 54: »Bio ma tko, samo kad je drag« piše: »Vezir u križ. kraj. vele kramarom: Kranjcem i platničkarom Ivakom; jer jedni i drugi privezaljke (pantlike) prodavaju.« Prema »križ. kraj « može se zaključiti da se misli na križevački kraj. A u bilješci pjesme 120 »Kapetan bolestan « piše: »Ova će pjesma biti od starijega vremena, kad je u Ivanić-gradu bio štop.) Pripjeva se tako.« Iz toga je jasno da je pjesma vezana uz Ivanić Grad.

${ }^{11} \mathrm{O}$ tome detaljno u: Tanja BARAN, Usmenoknjiževno nasljeđe križevačkoga kraja u kontekstu hrvatske književnosti 19. stoljeća, doktorski rad, Filozofski fakultet Sveučilišta u Zagrebu, 2012.
} 
prigorski Mirkovićev ciklus kao križevački prepoznat i u Institutu za etnologiju i folkoristiku jer je određen kao križevački lokalitet te je cijeli prepisan. ${ }^{12}$ Osim toga, zapisivač je, kada je već bio na širokom tertoriju kojeg je odredio »Križevačkom krajinom", vjerojatno zašao i u križevački kraj u užem smislu pa je logično zaključiti da je zabilježio i kajkavske pjesme koje su dominantne u Križevačkom i Kalničkom prigorju.

\section{Uređena, ali neobjavljena rukopisna zbirka}

Po samome se Mirkovićevu rukopisu nije lako snalaziti. Rukopis je maloga formata, tekst je gusto ispisan, a naslovi, odnosno određenja lokaliteta, nisu jasno odijeljeni. Dodatnu teškoću stvara više numeracija pjesama na svakoj stranici rukopisa. Originalne numeracije rukopisa nema, jedino su originalno numerirane pjesme. Sretna je okolnost ta što ipak postoji predgovor koji je potpisao I. St. Mirković I-Nin i, premda se u njemu doznaje malo informacija o samome rukopisu, posebno malo o prostornom određenju zapisa, iz njega se može razaznati nekoliko činjenica koje se samo iz rukopisa ne bi mogle doznati. Zapisivač se u predgovoru ponajprije koncentrirao na sitnije promjene koje je unio u pjesme u odnosu na izvornik koji je čuo od kazivača koje nije potpisao. No, napisao je i sljedeće:

»Štokavske su iz križevačke Krajine i hrvatske Posavine od Kratečkoga ovamo prema Sisku. Da me tko neobiedi, koj zna križevačke pjesme iz Kukuljevićeve sbirke, da ih nisam pisao, kako se govori i pjeva, evo mu unaprečac odgovora $(..) \ll$

Iz napisanoga se dade zaključiti da je zapisivač znao za zbirku narodnih pjesama, od kojih su neke i usmene iz križevačkoga kraja, Ivana Kukuljevića Sakcinskog, objavljene 1847., i da ju je imao u rukama. Mirković se vjerojatno zato i poveo za Sakcinskim pa pjesmama nije napisao točno mjesto zapisa, samo je, za razliku od Sakcinskog, koji je pjesme locirao križevačkom regimentom, granicom ili varmeđom, Mirković napisao da su pjesme iz križevačke krajine. Određenje pripadnosti zapisa križevačkoj sredini u današnjem smislu ipak je

\footnotetext{
${ }^{12} \mathrm{Te} »$ Pjesme iz Prigorja« vode se kao križevački korpus Deželićeva zbornika i u prijepisu rukopisa Instituta za etnologiju i folkloristiku u Zagrebu, rkp. 245. Uz taj cjelovit prijepis »Pjesama iz Prigorja « ispisana je signatura Matice hrvatske M. H. 186, a svaka od 36 pjesama ima svoj broj. Prva pjesma »Kratka popevka « numerirana je kao pjesma br. 168, a posljednja 36. »Ki dva ljube mrazi, zeli njega vrazi« numerirana je kao pjesma br. 204. U originalu rukopisa koji se čuva u Zbirci Matice hrvatske u arhivu Odsjeka za etnologiju HAZU u Zagrebu »Pjesme iz Prigorja« numerirane su od broja 18 do broja 54 i u kajkavskom su dijelu Mirkovićeve zbirke. Do razlike u numeriranju između originala i prijepisa došlo je zbog toga što je zapisivač Mirković drugi dio rukopisa, a to su kajkavske pjesme, počeo numerirati od broja 1, kao da se radi o novoj zbirci, dok se u prijepisu Instituta kajkavski dio rukopisa i brojevima nastavlja na prvi, štokavski dio zbirke. Zato su u izvorniku pjesme numerirane od 17 do 54, a u prijepisu od 168 do 204.
} 
Mirković olakšao time što je u rukopisu iznad pjesama napisao naslov »Pjesme iz Prigorja« pa se može pretpostaviti da je riječ o pjesmama zapisanim u potkalničko-križevačkom kraju. Spomenute sitnije promjene koje je Mirković unio u rukopis u odnosu na ono što je od kazivača čuo, u predgovoru je opisano sljedećim riječima:

»Mienjao nisam baš ništa, izuzam slovce e , gdje mora po analogiji da bude ie i je, a mienjao sam: a) jer ga nisam znao kako bi ga pisao, buduć da ga ovdje govore kao e, ondje kao ee, opet drugdje eㅡ, a kod Kratečkoga baš čisto: ie i ję; a usudio sam se promieniti b) jer za izvjestno reći mogu, da i Vuk, sabirajući svoju sbirku nije svuda čuo odprto: ie i je, pa ga je ipak svuda pisao. Što sam u genitivu množine ono ' $h$ ' pisao, činio sam ne samo književne sloge radi, koje nam treba, kano gladnu hljeba, nego i za to, što sam ga, ako ne svuda, a to na miestih liepo i razgovjetno čujao. Najbolji uztuk proti klevetnikom 'haovim'.«

Dalje u predgovoru Mirković opisuje kako je postupio s kajkavskim pjesmama. Na kraju predgovora otkrio je da je u zbirci moglo biti puno više pjesama, ali da nije htio zapisivati one za koje je znao da ih je Vuk Stefanović Karadžić zabilježio u svojim zbirkama:

»O sakupljivanju samom moram iskreno izpovjediti, da ako je tko šta iz šale i zabave radio, da sam ja ove pjesme kupio, a da mi nebiaše zadaća kupit ih, može jemstvo vat njihov malen broj, koj bi ipak bio u štokavskih narasao od 150 na 400, da se, da kako s njekom promjenom, ne nalaze već u Vukovoj sbirci, a ja ih izpušćah, da ne bude plagijata.»

Na kraju je napisao da je štokavske pjesme sam i slušao i zapisivao, dok su mu za kajkavske brojno stanje pjesama povećali neki »književni prijatelji i vrli domoroci«. Prije potpisa I. M. I-nin, uz koji je Mirković napisao: »U Zagrebu na svjetlo Marinje 1859.«, ispisao je želju: »Bog dao ovu sbirčicu nasliedila skoro sbirčetina!!«

Zanimljiv je podatak da je rukopis bio pripremljen za tisak odmah kada je završen 1859. godine. ${ }^{13}$ Nepoznato je zašto se objava rukopisa nije dogodila.

\section{Kajkavske »Pjesme iz Prigorja»}

Kajkavski dio rukopisa s »Pjesmama iz Prigorja«, za koji autorica ovoga rada drži da je veća vjerojatnost da pripada križevačkom usmenoknjiževnom korpusu, nego većina pjesama iz štokavskoga dijela rukopisa, smještene su na početku kajkavskoga dijela rukopisa, od broja 18 do broja 54 . Svaka pjesma ima naslov na kraju kojega je uglavnom točka, kao da je izjavna rečenica. Što se duljine stiha tiče, zbirka je veoma raznovrsna. Ima i šesteraca, osmeraca i dese-

\footnotetext{
${ }^{13}$ Prema opaskama u Očevidniku rukopisne građe akad. »Zbornika za narodni život i običaje juž. Slavena « rukopis je 1859. bio pripremljen za tisak i trebao je biti objavljen.
} 
teraca, dvanaesteraca, ima i zanimljivih metričkih kombinacija pjesama, poput kombinacije osmerca i sedmerca u pjesmi »Vince veseli srdce«.

Sadržajno su pjesme veoma raznolike, ima i ljubavnih i životnih i poučnih, a kao posebnost se izdvaja to što je u zbirci više pjesama vjerskoga sadržaja. Prema leksiku kojim su pjesme ispisane može se zaključiti da je rukopis prije nastao u križevačkim selima, nego u samome gradu. Leksičke kajkavske specifičnosti ispisane su u pokojoj bilješci na kraju pojedine pjesme, uz objašnjenje značenja na štokavskom jeziku. Primjerice u pjesmi »Svaki mora bit soldat« uz riječ spominati navodi se da to znači razgovarati, u pjesmi »Trava vehne devojke« uz riječ nakel objašnjava se da to znači na tlo. Prema naputcima iz pjesme vidljivo je da su se neke od pjesama i pjevale (npr. ispod pjesme »Marija k meši išla" piše: »Tako se pripjeva.«) te da su se neke pjesme pjevale baš uz određene običaje (npr. uz pjesmu »Hoćeš li me uzeti?« piše: »Kad se kod nas djevojku s djevojačtvom rastaje, onda plače, takov je u nas običaj.«). Zanimljiv je detalj da se u pjesmi »Kraljić i sv. Katarina u u prvom stihu sv. Katarinu zaziva »O presveta Katalena«. Lokalnoj varijanti imena Katarina - Kataleni posvećena je i jedna pjesma iz zbirke usmenoknjiževnog zapisivača iz križevačkoga kraja Andre Štanfela te više pjesama iz mlađe križevačke usmenoknjiževne zbirke u široj javnosti poznatoga križevačkog liječnika zapisivača Frana Gundruma Oriovčanina. Riječ je o Štanfelovoj pjesmi br. 31 »Š́tala se mudra Katalena» te o Gundrumovim zapisima pjesama: br. 55 »Dušo, Kato!« početnoga stiha »Katalena, dušo moja!«, pjesma br. 59 »Ružmarinku« prvoga stiha »Šetala se mlada Katalena« te pjesma br. 137 »Kata Katalena«.

Sv. Katalenu inače zazivaju i mještani križevačkoga sela Erdovca kojima je filijalni titular sv. Katarina. ${ }^{14}$ To je još jedan podatak koji je naveo autoricu ovoga rada na pretpostavku da se »Pjesme iz Prigorja« odnose na Kalničko prigorje.

\section{Sadržaj Deželićeve usmenoknjiževne zbirke i fragmentarne objave rukopisa}

Važno je još dokučiti zašto se uz ovu usmenoknjiževnu zbirku pjesama veže ime Đure Deželića, kada je iz opisa zbirke vidljivo da je svaka od pet zborničkih cjelina imala svojega zapisivača. U Deželićevu životopisu stoji da je on još kao učenik 1855. utemeljio »Društvo mladih rodoljuba« kojemu je glavna svrha bila prikupljanje i pjevanje pjesama da bi se za vrijeme apsolutizma spriječila germanizacija. Godine 1858. društvo je počelo izdavati zabavno-poučni list »Smilje«, kojemu je duša bio urednik Deželić. Prema želji roditelja godine 1856. ušao je u sjemenište u kojem je s kolegama nastavio rodoljubni rad. Oku-

\footnotetext{
${ }^{14}$ Podrijetlo oca autorice ovoga rada je iz križevačkoga sela Erdovca pa autorica ovoga rada taj podatak zna iz vlastitoga života.
} 
pljali su se oko lista »Bosiljak« i šaljivoga lista »Porkulab«. U »Zboru duhovne mladeži« bio je tajnik, knjižničar i predsjednik. ${ }^{15}$ Upravo se iz tih informacija može iščitati Deželićeva zainteresiranost za narodnu riječ i usmenu književnost pa se može pretpostaviti da je Deželić bio u nekoj vezi s Mirkovićem i da je njegov neobjavljeni rukopis štokavskih i kajkavskih pjesama 1877. predao Matici hrvatskoj. Kakva je to točno veza bila ne može se sa sigurnošću tvrditi jer je uvidom $u$ korespondenciju ${ }^{16}$ vidljivo samo to da su zapisivači svoje zbirke izravno slali Matici.

Od svih rukopisnih zbirki koje su iz križevačkoga kraja poslane Matici hrvatskoj baš je iz ove Deželićeve zbirke iskorišteno najviše pjesama u Matičinih deset objavljenih zbirki. Pjesme iz križevačkoga kraja objavljene su u petoj, ${ }^{17}$

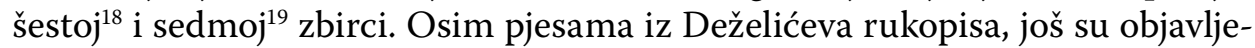
ne: jedna pjesma zapisivača Andre Štanfela iz Svetog Ivana Žabna u petoj Matičinoj zbirci 1909. godine i jedna pjesma zapisivača Stanka Miholića iz Mikovca kraj Svetog Petra Orehovca u šestoj Matičinoj zbirci 1914. godine. Zapravo, ni glavnina Deželićevih ni po jedna Štanfelova i Miholićeva pjesma nisu objavljene u cjelini, već se pokojim stihom donose kao primjer u dodatku zbirci gdje se prikazuju pjesme iz raznih hrvatskih krajeva koje opjevavaju određenu temu. Cijela je objavljena tek Deželićeva pjesma »Plivaj, plivaj, moj zeleni vijenče! ${ }^{20} \mathrm{u}$ sedmoj Matičinoj zbirci 1929. godine.

Spomena na pjesme iz Deželićeva zbornika ima u sve te tri zbirke Matice hrvatske.

U sadržaju pete zbirke stoji da je građa iz križevačke okolice Đure Deželića smještena u dodatku pod brojem 17 i 141 te da je građa iz Prigorja Đure Deželića također smještena u dodatku pod brojem 151.

Uvidom u zbirku zaključuje se da je u dodatku uz broj 17 na 421. stranici ispisan naslov »Djevojka i sunce« $\mathrm{i}$ da na str. 422 između ostalog piše:

»U Deželića (iz križevačke okolice, br. 76) sunce tuži djevojku Bogu, a ovaj odluči, da se 'kaštiga'. Oni će djevojku udati i dati joj čedo 'trikrat' ljepše od nje, / Pa ćemo joj čedo umoriti. / Za čedom će vrlo tugovati. / Tugovati, suze prol'jevati, / Kroz to projde sva lepota njena.»

\footnotetext{
${ }^{15}$ Prema: Znameniti i zaslužni Hrvati od 925. do 1925., Zagreb, Odbor za izdanje knjige, 1925, 60.

${ }^{16}$ Koresp. K.MH.80 (1 pismo; nije dat.); koresp. K.MH.86/1-K.MH.86/4 (4 pisma; god. 1879, 1903-1904).

${ }^{17}$ Nikola ANDRIĆ (ur.), Hrvatske narodne pjesme. Ženske pjesme, knj. peta, sv. 1, Zagreb, Matica hrvatska, 1909.

${ }^{18}$ Nikola ANDRIĆ (ur.), Hrvatske narodne pjesme. Ženske pjesme, knj. šesta, sv. 2, Zagreb, Matica hrvatska, 1914.

${ }^{19}$ Nikola ANDRIĆ (ur.), Hrvatske narodne pjesme. Ženske pjesme, knj. sedma, sv. 3, Zagreb, Matica hrvatska, 1929.

${ }^{20}$ Đuro, DEŽELIĆ, Plivaj, plivaj, moj zeleni vijenče!, u: Nikola ANDRIĆ (ur.) Hrvatske narodne pjesme. Ženske pjesme, knj. sedma, sv. 3, Zagreb, Matica hrvatska, 1929, 29.
} 
Uz broj 141. i naslov »Sestra otrovnica« na str. 513 između ostalog stoji sljedeće:

»U Deželića (iz križevačke okolice, br. 7.), ima jedna kajkavska varijanta, u kojoj djevojka ubija 'kaču jadovaču', te njenim otrovom truje brata, da ju može uzeti Ivo, al' je ovaj ne uzima, izgovarajući se: 'Kak si njemu, tako bi i meni.'«

U dodatku uz broj 151 iste zbirke je naslov »Hajdukova Jele« i među primjerima na str. 532 i 533 piše:

»U Deželića (iz hrvatskog Prigorja, br. 173) ima kajkavska varijanta, u kojoj je mati dala kćerku 'gizdavomu Pavlu', / Ki po gore hod, po hudeh pećinah, / K polnoći otide, po polnoći dojde, / I svû britku sablju krvavu donese, / Svû sablju krvavu i čovječju glavu.«

U sadržaju šeste zbirke piše da je građa iz križevačke okolice Đure Deželića smještena u dodatku pod brojem 28, 37 i 112 te da je građa iz Prigorja Đure Deželića također smještena u dodatku pod brojem 99 . Uz broj 28 i 29 na str. 321 stoji naslov »Zarad drugova prodao vjernu ljubu. - Ljuba Bogdanova.« Pod tim brojem u tekstu na str. 322 između ostalog piše sljedeće:

»U Deželića (iz križevačke okolice, br. 100.) Ivan prodaje ljubu 'gizdavim hajošem' za četiri tisuće dukata. Poplaćao dugove pa kupio bašču. Tu pod 'hruškom' bilo zakopano blago. Ali je to blago bilo 'zakleto', pa se zato javila Ivanu jedna 'sraka ptica, kobna gatalica', koja ga nauči, da 'ovčjom capom triput prekriži mjesto, gdje je novac bio ukopan', ali da 'ne čmrgne niti slovce'. On iskopa novac, pa otkupi svoju dragu.»

$\mathrm{U}$ toj istoj zbirci, u dodatku pod brojem 37. uz naslov »Ivo varalica « na str. 339 piše: »I u Deželića (iz križevačke okolice, br. 5.) vara Ivo Maru, prerušivši se u žensko ruho, po savjetu majčinu.«

Prema sadržaju, u toj bi zbirci trebao biti i treći spomen na Deželićevu građu iz križevačke okolice pod brojem 112. No, u dodatku zbirke teksta od broja 104 do 116 nema, tako da nema ni tekstova pod brojem 112.

Također se u dodatku šeste zbirke spominje i Deželićeva građa iz Prigorja. Pod brojem 22 i 100 te uz naslov »Preljino uzdarje. - Šala za šalu« na str. 393 stoji:

»U Deželića (iz kajkavskog Prigorja, br. 199.) šetao se junak u gradu Varaždinu, a djevojka ga gledala 's obluka'. On je pita: Kaj me tako gledaš z obluka divojka? / Kak da nesi nigdar videla junaka? / A ona mu odgovara: Ja ne gledam tebe z obluka divojka, / Kak da nesem nigdar videla junaka, / Neg ja tebe gledam, kaj bi prešla za te. / On veli, da je ne će, jer ne zna, kakove poslove umije, pa će joj zato dati 'jeno povesemce', da mu sprede gaće i rubaču, a od onoga, što joj preostane, neka sebi pokroji darove. Ona njemu nauzvrat daje zlatan prsten: $\check{Z}$ njega ti mi skuješ stalek za detešce, I ž njega mi skuješ još brdo i čunek / I četiri cevi za mene divojku! - 'Ale si pametna, z obluka divojka, / Anda ti buš moja mila draga žena.« 
U sedmoj Matičinoj zbirci na 29. stranici kao 56. je objavljena već spomenuta Deželićeva pjesma iz križevačke okolice »Plivaj, plivaj, moj zeleni vijenče!«

Iz pobrojenoga se dade zaključiti da sva iskorištena usmenoknjiževna građa iz križevačkoga kraja u zbirkama Matice hrvatske tematski stoji uz bok ostalim objavljenim usmenoknjiževnim zapisima iz drugih hrvatskih krajeva.

\section{Zaključak}

Deželićev zbornik usmenih lirskih pjesma, koji je od 1859. do 1886. stvaralo pet različitih zapisivača i u kojem je pet različitih zbirki iz više hrvatskih sredina, opsežna je i vrijedna usmenoknjiževna građa za cjelokupan hrvatski usmenoknjiževni prostor. Zbirka je svjedočanstvo kontinuiteta usmene književnosti u Hrvata, i u izvedbi i u zapisu.

Zbornik je osobito dragocjen za križevački usmenoknjiževni korpus jer u prvom, najstarijem dijelu zbornika, koji je od 1857. do 1859. zapisivao I. St. Mirković I-Nin, ima pjesama koje su određene Križevačkom krajinom. Te su pjesme unutar štokavskoga dijela zbirke, u kojoj su i pjesme iz Posavine, od Kratečkog do Siska, a budući da lokalitet zapisa uz pojedinu pjesmu nije označen, nemoguće je točno odrediti koja pjesma pripada kojem podneblju. Da se i zna koje su pjesme zabilježene u Križevačkoj krajini, postojao bi, kao i u mlađoj usmenoknjiževnoj zbirci Ivana Kukuljevića Sakcinskog, problem prostornog određenja Križevačke krajine, odnosno spoznaje o tome jesu li ti zapisi nastali unutar današnjih granica križevačkoga kraja ili su nastali u nekom drugom hrvatskom prostoru koji je teritorijalno pripadao nekadašnjoj velikoj Križevačkoj krajini. Ostalom križevačkom lirskom pjesničkom korpusu zabilježenom u 19. stoljeću bliže su kajkavske pjesme, njih 36, unaslovljene kao »Pjesme iz Prigorja«, koje su svoje mjesto našle u drugom dijelu zbirke.

Takvih propitivanja ne bi bilo da su zapisivači uz zapis svake lirske pjesme ispisali i točno ime lokaliteta na kojem su pjesmu zapisali s imenima kazivača koji su pjesme izricali. 


\section{Tanja Baran* \\ Copyists and Sites of Đuro Deželić's Oral Literature Collection}

Summary

This work analyses the place of origin of the extensive manuscript collection of oral literature compiled in the $19^{\text {th }}$ century and stored in Matica hrvatska under the name of the eminent Croatian cultural worker Đuro Deželić. As the manuscript does not state the exact place of the copying or the narrators' names, the locality, as well as the copyists themselves, is sought through the analysis of the then Croatian territorial organization and through the language or dialect in which the oral lyric poems were written. It is assumed that Deželić or someone else in Matica hrvatska supplemented the existing manuscript when he received new copies from an individual copyist. The description and analysis of this oral literature collection reveal that it contains a large corpus of lyrical poems written in the Štokavian and Kajkavian dialects, and that the places of origin are related to central Croatia, whereas the Kajkavian part originated in the Križevci region. The research concludes that the manuscript was created by five different copyists living in several Croatian environments, and that Deželić himself most likely did not take part in the creation of that manuscript collection as a copyist, although 1877 he stored it under his own name in Matica hrvatska.

Key words: copyists, Đuro Deželić, locality, manuscript collection, oral literature.

(na engl. prev. Guido Villa)

\footnotetext{
* Tanja Baran, PhD, Assis. Prof., University of Zagreb, Faculty of Croatian Studies; Address: Borongajska cesta 83d, HR-10000 Zagreb, Croatia; Croatian radiotelevision; Address: Prisavlje 3, HR-10000 Zagreb, Croatia; E-mail: tbaran@hrstud.hr.
} 